\title{
Sent to Heal! About the Biblical Roots, the History, and the Legacy of Medical Missions
}

\author{
Christoffer H. Grundmann ${ }^{a}$ \\ ${ }^{a}$ M.Th., D.Th., the John R. Eckrich University Professor in Religion and the Healing Arts at Valparaiso University, \\ Valparaiso, IN, USA
}

\begin{abstract}
The article situates medical missions within the broader context of the healing ministry of the Christian Church. In its first part it sketches the biblical tradition of this healing ministry and its meaning in the life of Jesus and his disciples. The second section provides a survey of Christian healing initiatives and care for the sick from the Early Church until the emergence of medical missions in the nineteenth century. The third part focuses on the development of the concept medical missions and its changes up to the present, while the final part briefly reflects on the lasting legacy of medical missions which is seen in that, if Christians ignore and neglect corporeality, they disgrace God the Creator and God's incarnation in Jesus Christ. The article therefore concludes that medical missions remind the Church that at the root of too spiritual a concept of mission and too materialistic a concept of health lies a misconceived, non-biblical anthropology which profoundly distorts the Christian witness to God incarnate in Christ.
\end{abstract}

\section{Introduction}

Christian medical missions are a particular expression of the healing ministry of the Church. Rooted in biblical tradition, especially in the ministry of Jesus and his charge to the disciples to cast out demons and to heal, medical missions emerged as a unique phenomenon in the nineteenth century within the context of the global expansion of Christianity and alongside developments marked by spectacular discoveries in medicine. Medical missions represent a special calling for people working in the healthcare professions to share their knowledge and skill with the deserving wherever their plight is heard as an expression of and witness to God's unconditional love to all people and all of creation.
To arrive at a meaningful understanding of this most interesting topic, I will discuss the biblical tradition of the concern for healing and its meaning and sketch in a history of Christian concern for the care of the sick and history of medical missions. Reflections on the vital and important legacy of medical missions for the Christian witness, in general, conclude my contribution.

\section{Biblical Tradition of the Healing Ministry and its Meaning}

Healing has been present among the people of God from its earliest times (Ex. 15:26: "I am the God who heals you"). ${ }^{1}$ Health and the power to heal were linked to faith in the God of Israel and

June 2014. Christian Journal for Global Health, 1(1):6-15. 
to obedient living according to God's commandments (Num. 12:10-16; 21:4-9; Isa. 38:1-6; Sir. 38:9-15). It is particularly in the New Testament that, unlike in any other religious tradition, healing is accorded a pointed significance. Healing, actually, became part and parcel of the proclamation of the Gospel, notably so in the ministry of Jesus himself. ${ }^{2}$ The Gospel accounts contain more than forty different healing miracles of Jesus and several brief summaries that impressively show that "Jesus went about all the cities and villages, teaching in their synagogues, and proclaiming the good news of the kingdom ... curing every disease and every sickness" (Matt. 9:35; emphasis mine).

The simple fact that Jesus healed clearly indicates that to him salvation had an unquestionable bodily dimension. In his ministry, healing became a legitimate corporeal aspect of salvation, albeit he never equated healing with salvation (see Mark 2:1-12). We also notice that numerous people were healed by Jesus or drawn to Jesus on account of his healings without becoming his disciples (Matt. 4:23-25; Mark 3:7; Luke 6:18-19; see also Acts 9:42). Impressive as they were, Jesus' healings evoked appreciation and fear, sometimes leading to awe, sometimes to rejection (Matt. 8:34; Mark 5:17). However, in Jesus' ministry, salvation was always accompanied by healing. No one who was sick or diseased was sent away without being restored to health fully. Jesus, thereby, showed that healing is characteristic of the reign of God (see Rev. 21:4; 22:2). Yet, it was Jesus' healing on a Sabbath that led to the accusation of his committing blasphemy entailing the decision by the authorities to destroy him (Mark 3:1-6; Matt. 12:9-14). This is a powerful, but oftentimes overlooked, indication of the core of the Gospel, namely to bring about healing by restoring the god-likeness of every human in an all-encompassing way. And indeed, the first Christians perceived Jesus' passion in just this way when they related it to Isaiah's prophecy, acknowledging, "He took our infirmities and bore our diseases" (Matt. 8:17; see also 1 Pet. 2:24). Looking up to Jesus on the cross makes all healing ministry stay focused on its genuine task, namely to restore God-likeness to all people.

However, Jesus did not keep the healing ministry all to himself. He also charged his disciples to do likewise. He sent "them out to proclaim the kingdom of God and to heal" giving "them power and authority over all demons" (Luke 9:1-2; also see 10:9; emphasis mine), a mandate that the risen Christ reconfirmed, "And he [the risen Lord] said to them [the disciples], 'Go into all the world and proclaim the good news to the whole creation ... By using my name ... cast out demons; ... lay ... hands on the sick, and they will recover'" (Mark 16:15-18). We know that the Apostles heeded this command and that their ministry was blessed accordingly as is told in The Acts of the Apostles. Peter healed a crippled beggar at the entrance gate to the temple (3:1-8), the paralytic Aeneas at Lydda (9:32-35), and he raised the dead Tabitha at Joppa (9:36-41). Ananias healed Paul from his blindness at Damascus (9:17-19). Paul healed a crippled man at Lystra (14:8-11), the diseased father of Publius on the island of Malta (28:8), and Paul raised a dead person, too, viz., the young Eutychus at Troas (20:9-12). These are only the more outstanding examples of healings performed by Apostles. ${ }^{3}$ Besides healing in the name of Jesus and the anointing of the sick "with oil in the name of the Lord," (Jas. 5:14) healings were also perceived during the apostolic age without any reference to Jesus or his name, namely, as the work of the Holy Spirit; Paul, for instance, counted healing among the many spiritual gifts present in the Christian congregation (1 Cor. 12:4-10).

In further careful study of these texts, we notice certain differences between the various accounts within scripture. While the Synoptics, that is the first three gospels Matthew, Mark, and Luke, view Jesus' healings as efficacious signs of the presence of God the Redeemer and as manifestations of "the kingdom of God at hand" (Matt. 12:22-32; Luke 10:9; 11:17-23), John regards healings as revelatory "signs" of Jesus' Messiahship (John 3:2; 5:36; 9:3; 20:31). While 
Jesus healed by the authority of God incarnate, his disciples did so in his name (Mark 16:17; Acts 3:6). This does not mean that they used Jesus' name as a magic formula; however, it does mean that the very ministry of the Apostles was vested with an authority not their own. Furthermore, the disciples had been mandated to bear witness to a power which was not at their disposal, something they painfully experienced when their well-intended attempts at healing failed (Matt. 17:14-20; Mark 9:14-29; Luke 9:3743). They, thereby, came to realize the qualitative difference existing between their efforts and the powerful ministry of their Lord and Master, a difference which Christian theology would later describe as "eschatological."

In sum, there is no one single biblical concept of healing to be found in scripture. The biblical tradition, rather, bears witness to a diverse perception of healing from the times of the Old Testament to Jesus and his ministry and the apostolic era. Yet, despite this diversity, healing is understood across the board as a result of God's workings, a sign of the Kingdom of God at hand, and as a foretaste of what is to be enjoyed by all at the end of times when God "will wipe away every tear," because "death ... mourning and crying and pain will be no more ..." (Rev. 21:4).

\section{Christian Healing Ministry Prior to Medical Missions}

The writings of the Church Fathers, Christian authors from the second to the sixth century $\mathrm{AD}$, refer frequently to the ministry of healing. This, evidently, reflects their argument with the then very popular Greek healing-cult of Asclepius. Asclepius was revered as "the Savior" in the Hellenistic world over against which the Early Church had to articulate the specifics of Christ. This confrontation made them to confess Christ as being "the Savior of the world" in order to indicate that Christ actually did overcome death itself, which Asclepius was unable to accomplish. Another argument for the care of bodily needs was advanced by the North African
Church father, Tertullian (c. 160-230), in the 3rd century AD. Arguing against the radical dualistic separation of body and soul by the Gnostics, Tertullian reminded his contemporaries that "the body is the pivot of salvation" (caro cardo salutis), because Christians not only confess that the corporeal world is God's creation and believe in the resurrection of the body, but since God truly became incarnate--that is: enfleshed in Jesus Christ--the body is made the pivot of salvation. ${ }^{4}$

Adolf v. Harnack, the eminent nineteenth century church historian of the Early Church, concluded his seminal study on the topic with the remark:

Christian religion and the care of the sick have traveled a long way together in the course of history; as a result, they now are inseparable. ... The influence and future of the church depend on her caring for those who suffer spiritually and physically. ... This is definitely the meaning of the Gospel of the savior and of salvation. The Early Church understood this comprehensively. And the only way that the Old Church remains young and the Young Church remains the old is that it keeps and preserves this understanding of the Gospel in its fullness. ${ }^{5}$

However, despite the clear biblical mandate and the importance of healing in spreading the good news of salvation for all in the first centuries of the Christian Church, ${ }^{6}$ active engagement in healing was hampered somewhat by the instruction that disciples should not make their living by healing. The disciples were not only charged to "cure the sick;" they also were reminded that they received their special gifts "without payment" and, therefore, had to share these "without payment" (Matt. 10:8). To understand this directive, one has to know that the then very popular healing cults of Asclepius and Serapis were noted for their greediness. It was a common practice - not unlike today's healthcare system - to demand more and more donations for whatever benefit or blessing for which the petitioners asked, making healing 
extremely expensive and, thus, unaffordable for the most desperate. To pursue the art of healing in this environment as a way of earning a living, therefore, would have compromised the proclamation of salvation for all in no small degree.

What could be done without compromising the faith instead was caring for the sick, including those beyond one's own kin, which was not a popular thing to do. Solidarity with members in need of one's own family was common practice, of course, but to care for those outside, the strangers and those in desperate situations shunned by society at large, was not regarded as an obligation. In opposition to this attitude, Christians were called to be concerned with those in need beyond their own families by feeding the hungry, giving drink to the thirsty, welcoming strangers, clothing the naked, caring for the sick, and visiting the incarcerated (Matt. 25, 31-46), witnessing to God's unconditional love for all humankind. They, thereby, also fundamentally changed the overall societal attitude towards the sick, something impressively epitomized in the parable of the Good Samaritan (Luke 10:25-37). Thus, caring for the sick and destitute as a charitable work of compassion eventually became the hallmark of Christianity, while active involvement in the art of healing was not on the agenda, at least not until the nineteenth century. ${ }^{7}$ The Latin speaking church of the West, rather, developed an increasing dislike for the practice of medicine, especially surgery in later centuries. In 1215, the fourth Lateran Council, then the supreme authority of Western Christianity, ruled that no cleric should practice surgery, because a priest should never shed blood and for fear of committing unintentional homicide. ${ }^{8}$ This was a wise decision considering the actual danger any surgical procedure posed in a time without anesthesia and antiseptic, and without sterile operating theaters so that postoperative death due to infection occurred frequently.

Things changed, somewhat, with the discovery of the "New World" and the Spanish and Portuguese divisions of newly discovered ter- ritories by the Treaty of Tordesillas of 1494 when the care for the sick became an official duty for missions and missionaries. The Spanish "Council for the Indies" (Consejo de las Indias) ruled that hospitals were to be built at every new settlement under their rule, while in the territories under Portuguese patronage charitable organizations, called Misericórdia-societies, were established, whose members vowed to care for the needy in their community as had become a pious practice back home at Lisbon since 1498. Physicians were hired on the basis of need to work in the hospitals while Christian brothers and sisters or members of the local Christian community cared for the daily needs of patients. During the sixteenth and seventeenth centuries, Franciscan and Jesuit missionaries faced with unspeakable suffering could not avoid getting involved in the healing ministry despite the official prohibition, whereas the early Protestant missions of the eighteenth century such as the Danish-Halle Mission and the Herrnhut Brethren had no issue with sending out professionally trained physicians into the missions. These physicians, however, were not regarded as missionaries proper but as hired professionals to attend first of all to the health-care needs of the missionaries suffering from tropical diseases, especially malaria, and also, if time, funds, and skill permitted, to treat indigenous people in case of illness. Yet, the impact of these initiatives was severely impeded by the kind of medical help which the physicians of that age could actually render, because such help was hardly any different from or superior to established indigenous systems of healing in place in the respective cultures. ${ }^{9}$

\section{Medical Missions Past and Present}

It was as late as the nineteenth century when medicine morphed from an old fashioned, authority-bound scientia into a modern science uncompromisingly studying human physiology and diseases. Although this approach had begun long before, ${ }^{10}$ it gained significant momentum in the second part of the nineteenth century, thanks, first, to the discovery of anesthesia (1846) and 
anti-sepsis (1847/1867), leading to the previously unimaginable rise of successful surgeries; second, the detection of the importance of public hygiene and sanitation - providing safe drinking water and proper disposal of sewage - for the prevention of epidemics (1854/1859/1888); and, thirdly, thanks to laboratory based cellular pathology bringing about the age of bacteriology (Rudolf Virchow, 1821-1902; Robert Koch, 1843-1910; Ronald Ross, 1857-1932) and with it the discovery of the disease causing pathogens of epidemics at the level of their causation. This, consequently, led in rapid succession to the development of appropriate measures of disease prevention and effective treatment. ${ }^{11}$ Physicians were then truly enabled to heal diseases previously considered fatal. The new medical breakthroughs enabled Christian physicians to reconsider once again the scriptural charge to be "sent to heal" by their Lord and Master. As much as medical missions is thus "an epiphenomenon of the development of medicine," 12 it is also an epiphenomenon of the great missionary movement of the nineteenth century ignited by the Great Evangelical Revival, thanks to which many pious individuals dedicated their gifts and life to missionary service; medical missionaries, in particular, perceived their work as bearing witness to disinterested benevolence. ${ }^{13}$

Formally organized medical missions first took shape with the foundation of the Medical Missionary Society in China at Canton (Guangzhou) on February 21, 1838, of which the American Rev. Peter Parker, M.D. (1804-1888) was its most renowned representative. ${ }^{14}$ This Society was a joint venture by missionaries, physicians, and philanthropic businessmen who were of different nationalities (British, American, Chinese, Indian), belonged to different denominations (Presbyterian, Congregationalist, Episcopal), and different religions (Christians, Parsi, Chinese). They all joined hands in this venture to guarantee institutional backing of hospital based medical services provided gratuitously to the destitute by missionary physicians trained in rational-scientific medicine.
The program of the Society was stated, as follows:

We have ... the pleasure of explaining our object, and of inviting the coöperation of all those who wish to mitigate the sufferings of their fellow-men. ... To restore health, to ease pain, or in any way to diminish the sum of human misery, forms an object worthy of the philanthropist. But in the prosecution of our views we look forward to far higher results than the mere relief of human suffering. We hope that our endeavors will tend to break down the walls of prejudice and long cherished nationality of feeling, and to teach the Chinese, that those whom they affect to despise are both able and willing to become their benefactors. ... It has been sometimes objected, that to attend to the diseases of men is not the proper business of a missionary. This objection may be shortly answered by a reference to the conduct of the Savior and his apostles, who, while they taught mankind things that concerned their eternal interests, were not indifferent to their bodily sufferings. ... To the various missionary Boards whose coöperation is sought, we would respectfully say, imitate Him whose gospel you desire to publish to every land. Like Him, regard not as beneath your notice the opening the eyes of the blind and the ears of the deaf, and the healing of all manner of diseases. Until permitted to publish openly and without restraint the truths of the gospel, neglect not the opportunity afforded of freely practicing its spirit. Scatter to the utmost its fruits, until welcomed to plant the tree that produces them - the "tree of life." 15

The interdenominational, even interreligious, approach coupled with pragmatic concerns for temporal wellbeing, however, rendered medical missions suspicious in the eyes of those who were solely interested in the pursuit of straight-forwardly spiritual goals. ${ }^{16}$

As medicine was becoming more and more powerful and, as in the wake of the evangelical 
revival inspired by Dwight L. Moody (18371899), an ever increasing number of pious physicians decided to serve as missionaries yearning for "the evangelization of the World in this generation," medical missions became "the heavy artillery of the missionary army," as Herbert Lankester, then secretary of the Medical Committee of the Church Missionary Society (CMS), London, characterized it. ${ }^{17}$ By the turn of the twentieth century, medical missions were deemed so essential that it was declared in 1900 that no mission could "be considered fully equipped that has not its medical branch." 18

While statements like these suggest that medical missions were being universally recognized, reality looked different. Only a fraction of Protestant missionary societies $(26 \%)$ were engaged in medical missions, and their medical staff, both male and female, foreign and indigenous, represented just five percent of missionary personnel overall. ${ }^{19}$ These figures have continued to dwindle since they reached their zenith in 1923, with (about) 1157 medical missionaries out of a total of 20,569 missionaries. ${ }^{20}$ Yet, medical missions had become a topic of real concern for Protestant missions by that time, indeed, albeit a controversial one, while Roman Catholicism, bound by canon law, was remarkably hesitant to embrace the concept at all. With the exception of one remarkable initiative on the island of Malta during 1881-1896 — the Training Institute for African Medical Catechists - by Cardinal Lavigerie (1825-1892), ${ }^{21}$ medical missions simply were non-existent among Catholics. This, however, changed dramatically once the Society of Catholic Medical Missionaries (Medical Mission Sisters, SCMM) was founded by Austrian Anna Dengel, M.D. (1892-1980) in Washington D.C., in 1925, and once the Vatican revoked the former ruling on the study and practice of medicine by religious in $1936 .^{22}$

After the disruption caused by World War II (1939-1945) and many violent struggles for national independence from colonial powers in African, Asian, and Latin American countries since the mid-1950s, medical missions were seriously questioned. This had to do with the formation and development of national healthcare administrations and departments as well as with the founding of the World Health Organization, WHO, in 1948, as a global agency for general health-care issues and politics across the globe. Christian medical mission hospitals found themselves in an emergent competition with kindred government and private enterprises while rapid advancements in medical technology constantly demanded expensive upgrades of existing facilities, quickly depleting the limited funds of mission societies and churches "Old" and "Young." Priorities had to be set regarding the task and ministry of healing and how it would be best to invest the scarce resources at hand, priorities which were to be critically informed by the Gospel, of course. To do this, an international conference of people engaged in medical missions was convened at Tübingen, Germany in 1964 by the World Council of Churches (WCC) and the Lutheran World Federation (LWF). The conference addressed the basic questions, "is the commission to heal an integral part of the ministry of the Church?" and "what kind of service is the Church called to give in the performance of its mission?" ${ }^{23}$ Struggling with these questions for about a week, the participants finally arrived at the unanimous opinion "that the Church does have a specific task in the field of healing which arises from its place in the whole Christian belief about God's plan of salvation for mankind." ${ }^{24}$ The momentum of that conference and the widely read final report, The Healing Church, in 1968, led to the creation of the Christian Medical Commission (CMC) by the World Council of Churches, charged "with responsibility to promote the national co-ordination of church-related medical programmes and to engage in study and research into the most appropriate ways by which the churches might express their concern for ... health care." 25

At the present time, the task of medical missions is seen in a much broader context than before. This reflects the post-colonial situation of 
a truly globalized, ecumenical Christianity demanding cooperation across national and denominational fault lines as well as across various disciplines. Christian medical work cannot any longer stay content with only focusing on suffering individuals and providing hospital care amidst a situation which deprives the most deserving from having access to it. Those who can afford health care will always have options to have their needs met, whereas the impoverished have none. This is not just fate; it, rather, is the product of existing injustice. Oftentimes, the poor lack sufficient nourishment and live in unhygienic conditions which expose them to preventable diseases in the first place. This means, practically, that contemporary Christian medical missions have not only to be concerned about the immediate signs of ill health in individual patients. Modern Christian medical missions concerned about bringing health and healing to the marginalized and deprived have to be concerned about sanitation and safe drinking water, too, about providing proper care for pregnant women and training traditional midwives in safe methods of delivery, and the adequate supply of basic generic drugs for the most common diseases; modern medical missions done by Christians have also to be concerned about securing sufficient, nutritious foods and, last not least, about health education with a focus on enabling the health care potential of families and local communities to flourish, which has also proven to be most effective in successfully coping with the HIV/AIDS pandemic. ${ }^{26}$ In prioritizing primary health care (PHC), as this concept is called, and pragmatically accepting the cooperation with indigenous people across various denominations, disciplines, and with governments, Christian or not, medical missions turned away from hospital-centered medical work fashioned according to the financial affluence of a technocratic, secular culture dominant in the western hemisphere and developed a health-care program so effective, that, finally, the World Health Organization (WHO), too, adopted it in 1978 at Alma Ata, Kazakh (Declaration of Alma
Ata) with the motto "Health for all by the year 2000." ${ }^{27}$ Since then, individual nation-states have changed their healthcare focus in order to show quick results for the sake of securing World Bank funding, etc. Christian medical missionaries, however, continue to pursue the course and vision of the PHC approach. Their skillful use of medicine for the sake of bringing about life in abundance (John 10:10) and preventing untimely death (particularly among those most neglected, the poor, including, today especially, the victims of the HIV/AIDS pandemic) at once witnesses to the corporeality of salvation and to the proper use of medical knowledge, nursing skills, and operative funds for the benefit of all, thereby, profoundly critiquing other ways of doing medicine.

A new phenomenon, availing of today's fast and frequent air-travel and the wellfunctioning global communication networks and impacting medical missions, appeared in the 1980s, namely, short-term medical missions by physicians, nurses, and untrained helpers to medically underserved areas of the world and for instant disaster relief. These trips may last from a couple of weeks to several months and are carried out by highly motivated individuals who give of their time, their skill, and their funds. ${ }^{28}$ However, as laudable as such initiatives appear to be at first sight, they do not solve prevailing issues due to lack of proper record-keeping, of qualified follow-up, of oftentimes deficient coordination with other agencies, and by a common dearth of intercultural competence. ${ }^{29}$ To do medical mission work, good intentions simply are not good enough. Untamed good intentions actually cloud the sober minded perception of what truly gets achieved $^{30}$ and, thus, become counterproductive to the proclamation of the Gospel.

\section{The Legacy of Medical Missions}

It has been argued above that the goal of the ministry of Jesus was to reinstate the Godlikeness of all human beings bereft of it, which later became the well-known leitmotif for Christian caritas. Surveying the history of the 
Church, one cannot but give due honor and credit to the many works of charity which people felt called to do with the intention to better the fate of their fellow human beings and alleviate suffering "in the name of Jesus Christ." Despite all justified criticism of the Church's involvement in worldly strife, the history of Christianity with its establishment of charitable institutions like hospitals, hospices, orphanages, and the many programs devoted to caritas is also one of genuine compassion and care. The healing ministry, as it has found expression in medical missions, however, while pursuing the same objective, acts differently in a very distinctive way unlike any other, namely, by drawing attention to the bodily and corporeal dimension of salvation.

As every physician attempts to restore patients to the state of health they were in before they suffered from an injury or disease, an attempt which is called restitutio ad integrum (restitution to the former state), so, too, does any proclamation of the Gospel attempt to bring people back into the presence of the living God as it once was in the very beginning. The good news of the Gospel is that their original integrity is restored to humans by the reconciliation brought about in Jesus Christ (Ro. 6:1-11; Heb.7:27). This restitutio ad integritatem (restitution to original integrity) is commonly termed "salvation," but it has also occasionally been described as a "healing." ${ }^{31}$ Christians called to proclaim this restoration to original integrity cannot do so without reference to the passion, cross, and resurrection of Jesus Christ. That is, Christians cannot but be mindful of corporeality. If they ignore and neglect corporeality by only being concerned spiritually, their proclamation disgraces God the Creator and mocks God's incarnation in Jesus Christ.

It is precisely in this way that medical missions challenge the common conviction that the soul is more precious than the body. While most of the Revivalists of the 19th century viewed it to be the case, one among them, who was deeply immersed in the revival himself, but a physician, too, chastised this conviction sternly by stating, "To merely talk piously and tell suffering people of a future state, while neglecting to relieve their present needs, when in our power to do so, must be nauseating both to God and man, and certainly is a libel upon the Christianity Christ both taught and practiced, in which He combined care for the whole being of man, body and soul." ${ }^{32}$ At the root of too spiritual a concept of mission and too materialistic a concept of health lies a misconceived, nonbiblical anthropology which profoundly distorts the witness to God incarnate in Christ; caro cardo salutis, the body is indeed the pivot of salvation.

\section{Endnotes and References}

1. Scripture passages are quoted from the New Revised Standard Version (NRSV), 1989.

2. For a solid exegetical study of the topic see Van der Loos H. The miracles of Jesus. Preston TS, translator. Leiden, Boston: Brill; 1962. See also Seybold K, Mueller, UB. Sickness and healing. Stott DW, translator. Nashville: Abingdon; 1981.

3. There are several additional summary accounts of like activities in Acts. See 5:15-16; 8:6-7; 19:11-12; 28:9. Other references to "wonders and signs" of the apostles may be found in Acts $2: 43 ; 5: 12 ; 6: 8 ; 14: 3$.

4. Tertullian. De resurrectione carnis liber [Treatise on the resurrection]. Evans E, editor [introduction, translation, and commentary by Evans E]. London: S.P.C.K.; 1960. p.26. 
5. Harnack Av. Medicinisches aus der ältesten Kirchengeschichte. In: Texte und Untersuchungen zur Geschichte der altchristichen Literatur. Leipzig: Akademie-Verlag; 1982. 8(4): 37-147 [quote, p. 147; original emphasis] See also: Harnack Av. The mission and expansion of Christianity in the first three centuries. New York: Harper \& Brothers; 1961. [esp. p.101-46].

6. Amundsen DW, Ferngren GB. The early Christian tradition. In: Caring and curing - Health and medicine in the western religious traditions. Amundson DW, Numbers RL, editors. New York, London: MacMillan Publishing; 1986. p. 40-64.

7. Sigerist HE. Civilization and disease. College Park, MD: McGrath; 1970. p.69-70.

8. Namely in constitution 18 (Clerics to dissociate from shedding blood); See Tanner NP, editor. Decrees of the ecumenical councils: From Nicea I to Vatican II. Washington DC, MD: Georgetown University Press; 1990. [vol. 3] p.244.

9. See Grundmann $\mathrm{CH}$, Sent to heal! — Emergence and development of medical missions. Lanham, MD: University Press of America; 2005. p.22-37.

10. See the anatomical drawings of Leonardo da Vinci [1452-1519] in O'Malley CDE, Saunders JB de CM, editors. Leonardo on the human body - The anatomical, physiological, and embryological drawings of Leonardo da Vinci [with translations, emendations, and a biographical introduction]. New York: Gramercy Books; 2003. Vesalius A [1514-1564]. De humani corporis fabrica libri septem [Seven books on the structure of the human body]. Garrison DH, Hast MH, editors. Evanston, IL: Northwestern University; 2003. Harvey W. [1578-1657]. The works of William Harvey. Willis R, translator. London: Sydenham Society; 1847.

11. Ackerknecht EH. A short history of medicine. Baltimore, MD: The Johns Hopkins University Press, 2nd ed.; 1982. p.145-74.

12. Walls AF. "The Heavy artillery of the missionary army": The domestic importance of the nineteenth century medical missionary. In: The church and healing. Sheils WJ, editor. Oxford: Basil Blackwell; 1982. p.287.

13. "Disinterested benevolence" was regarded as the hallmark of redeemed Christians. Its prototype was found in God offering his own Son — and as such, offering himself — on the cross for the redemption of all. See Hopkins S. An inquiry into the nature of true holiness. In: The Works of Samuel Hopkins. 1773 [reprint, 1987]. [volume 3] p. 5-66.

14. See Anderson GH. Peter Parker and the introduction of western medicine in China. In: Mission Studies. 2006: 23(2); p. 203-238. For a more general overview see: Balme H. China and modern medicine - A study in medical missionary development. London: United Council for Missionary Education; 1921.

15. This selection of quotes is based on The medical missionary society in China - Address with minutes of proceedings; Canton 1838; p.11-5,18-21. Original emphasis.

16. Grundmann C. Sent to heal! — Emergence and development of medical missions; p. 65-71, 92-5.

17. Walls AF. "The Heavy artillery of the missionary army": The domestic importance of the nineteenth century medical missionary. p.290. See also: Browne SG, editor. Heralds of health — The saga of Christian medical initiatives. London: Christian Medical Fellowship; 1985.

18. American Tract Society. Report of the ecumenical missionary conference on foreign missions, held in Carnegie Hall and neighboring churches [vols. 1 and 2], 1900 Apr 21-May 1; New York; 1900. [vol 2] p.199.

19. Dennis JS. Centennial survey of foreign missions - A statistical supplement to "Christian missions and social progress," being a Conspectus of the achievements and results of evangelical missions in all lands at the close of 
the nineteenth century. New York, Chicago, Toronto: Fleming H. Revell Company; 1902. And see: Grundmann C, Sent to heal! . p.150,159.

20. Beach HP, Fahs CH, editors. World Missionary Atlas - Containing a directory of missionary societies, classified summaries of statistics, maps showing the location of mission stations throughout the world, a descriptive account of the principal mission lands, and comprehensive indices. Edinburgh: Edinburgh House Press; 1925.

21. Grundmann C, Sent to Heal! p.121-124.

22. Dengel A. Mission for Samaritans. Milwaukee: The Bruce Publishing Company; 1945. p. 8-29.

23. McGilvray JC. The Quest for Health and Wholeness. Tübingen: German Institute for Medical Missions; 1981. p.9. [original emphasis]

24. McGilvray JC. The Quest for Health and Wholeness. p.13.

25. McGilvray JC. The Quest for Health and Wholeness. p.41. See also: Ewert DM. A new agenda for medical missions. Brunswick, GA: MAP International; 1990.

26. See Martin J. Primary health care and AIDS control programs. In: The handbook for AIDS prevention in Africa. Lamptey P, Piot P, Gringle R, editors. Durham, NC: Family Health International; 1990. p. 211-9. See also: Bruyn dM, Hoeven Fvd. Primary health care and AIDS: African experience. AIDS Bulletin.1994 Apr; 3(1):6-7. See also: Pfeiffer J, Montoya P, Baptista A, Karagianis M, Morais Pugas Md, Micek M, Johnson W, Sherr K, Gimbel S, Baird S, Lambdin B, Gloyd S. Intergration of HIV/AIDS services into African primary health care: Lessons learned for health system strengthening in Mozambique - A case study. J Int AIDS Soc. 2010 Jan; 13(3): http://dx.doi.org/10.1186/1758-2652-13-3. See also: Joulaei H, Motazedian N. Primary health care strategic key to control HIV/AIDS in Iran. Iran J Public Health. 2013; 42(5):540-1.

27. McGilvray JC. The Quest for Health and Wholeness. p.70-80.

28. See for instance, Kuhn W, Kuhn S, Gross H., Benesh S, editors. Global medical missions: Preparation, procedure, practice. Enumclaw, WA: WinePress Publishing; 2007.

29. Montgomery LM. Short-term medical missions: Enhancing or eroding health?. Missiology. 1993 July;21(3): 333-41. And Priest RJ, Dischinger T, Rasmussen S, Brown CM. Researching the short-term mission movement. Missiology. 2006 Oct;34(4):431-50. http://dx.doi.org/10.1177/009182969302100305

30. For a pointed argument against good-will actions see Illich I. To hell with good intentions. [internet] [cited 2014 March 3] Available from http://www.swaraj.org/illich_hell.htm

31. The Formula of Concord, one of the Lutheran confessional texts, describes the ministry of Jesus, the restitution ad integritatem as "healing' the 'rift' between God and humanity." [See: Solida Declartio I= De Peccato originis/Original Sin], Tappert TG, Pelikan J, Fischer RH, Piepkorn AC, editors. The Book of Concord: The Confessions of the Evangelical Lutheran Church. Philadelphia: Fortress; 1959; p.511 — For the medical maxim of "restitutio ad integrum" and its relation to the "restitutio ad integritatem" see Schipperges H. Motivation und Legitimation des ärztlichen Handelns. In: Krankheit, Heilkunst, Heilung. Schipperges H, Seidler, Unschuld P, editors. Freiburg/München: Alber; 1978; p. 447-89.

32. Dowkontt GD. Murdered millions. New York City: The Medical Missionary Record. 5th ed; 1897; p.24.

June 2014. Christian Journal for Global Health, 1(1):6-15. 
Before joining Valparaiso University in 2001 Prof Grundmann, an ordained Lutheran minister, worked in Caracas, Venezuela, served as a missionary and theological teacher in South India (TTS Arasaradi, Madurai) and has been the theological consultant to the German Institute of Medical Missions at Tübingen, Germany. From 1992 - 1999 he taught at the University of Hamburg, Germany, where he earned a couple of doctorates in the history of missions and missiology with a special focus on medical missions and healing.

http://faculty.valpo.edu/cgrundma.

\section{Peer Reviewed}

Competing Interests: None declared.

Correspondence: Prof. Christoffer Grundmann, Valparaiso University, Valparaiso, IN 46383-6493 USA

Christoffer.Grundmann@valpo.edu

Cite this article as: Grundmann, C.H. Sent to heal! About the biblical roots, the history, and the legacy of medical missions. Christian Journal for Global Health (August 2014), 1(1):6-15.

(C) Gundmann, $\mathrm{CH}$. This is an open-access article distributed under the terms of the Creative Commons Attribution License, which permits unrestricted use, distribution, and reproduction in any medium, provided the original author and source are properly cited. To view a copy of the license, visit http://creativecommons.org/licenses/by/4.0/

www.cjgh.org 